\title{
A General Overview of the Educational Programmes of the Hungarian Football Academies
}

\author{
Imre Fenyő', Dávid Rábai ${ }^{2}$ \\ Recommended citation: \\ Fenyő, I., \& Rábai, D. (2020). A general overview of the educational programmes of the Hungarian football academies. \\ Central European Journal of Educational Research, 2(2), 101-110. https://doi.org/10.37441/CEJER/2020/2/2/7919
}

\begin{abstract}
In the course of our research, we surveyed the educational programmes of the football academies of Hungary. We wished to reveal the educational aspects of the life of the students at the football academies. The purpose of our project is to comparatively analyse the formal and conceptual dimensions of the educational programmes of the academies through an analysis of the documents of the academies concerned. We also conducted semistructured interviews with the heads of the social- and educational sections of the academies $(\mathrm{N}=6)$. We used the results of the interviews to check-confirm or refute-the results we found. We believe that the findings of our research make it possible for us to better understand the elements and value-based components of the educational dimensions of the football academies. In this way, our survey is similar to the projects of researchers who worked with local educational programmes (for example, Brezsnyánszky et al., 2000). As a conclusion of our research, we may point out that both the formal and conceptual dimensions of the educational programmes of the individual football academies are strongly heterogeneous, and the quality of their pedagogical programmes is often questionable. The results yielded by the analysis of the interviews suggest that although an educational-social department is present at each of the academies, some our former conclusions in connection with the general standards of the educational work were confirmed by the answers we received from our respondents. The academies, almost without an exception, produce their own educational programmes and carry out their educational work individually, and do not cooperate with the other institutions. There is, consequently, no uniform and standard educational work, and there is no professional documentation of the work going on either. In this way, the quality of educational work is not really able to improve.
\end{abstract}

Keywords: football academies, educational programmes, document analysis, interviews

\section{Introduction}

Our research was necessitated by the fact that academy-type institutions where new generations of football players are brought up. Thousands of young Hungarian children live, play and learn in these academies. It is, however, still unclear how effectively and consciously these academies are able to perform their required educational missions. Since the academies are supposed to provide school-type education in addition to the training and education in sport, and since these are boarding institutions, where children are away from their families, it is highly important to analyse and evaluate the quality of the educational programmes going on at the academies.

The importance of such a research programme is further improved by the high popularity of football in the 21 st century. In Hungary the popularity of football is outstanding, as half the registered sportspeople are footballers (Orosz 2009). On the other hand, international success has escaped the Hungarian football teams in the recent years. Several experiments have been launched in order to improve the situation in Hungary. One such effort addressed the improvement of the situation of the replacement of players (Rábai, 2018). The projects have included

\footnotetext{
${ }^{1}$ University of Debrecen, Hungary, Faculty of Child Education and Special Education, associate professor. e-mail: fenyoimre@gmail.com

${ }^{2}$ University of Debreceni, Hungary, Faculty of Child Education and Special Education, assistant lecturer e-mail: david.rabai67@gmail.com ORCID: 0000-0002-9180-8325
} 
the start of various programmes for children, shaping and re-shaping the strategies of replacement training and the creation of football academies since 2001.

Nerland \& Saether (2016) argue that football academies have become an important means of promoting the developing of the young football players. Learning to play football in the environment provided by the academy has a number of advantages: highly experienced coaches and excellent infrastructure await and receive young players in these special institutions (Collin \& Young 2000; Pruna et al., 2018). It is, however, still a question what significance the academies ascribe to the strictly educational aspects. In other words: what is the quality of the eduational-pedagogical work going on at the academies? In search of an answer to that question, we decided to examine the educational programmes of the specific institutions, and the educational activities based upon those programmes. Furthermore, we intended to reveal whether the academies make these programmes available to parents and those potentially interested in the academy, and in this way the educational programmes are a part of the "image" of the academy. We wished to reveal the specific, tangible and verifiable elements in the educational programmes as these elements may serve as a foundation for the quality assurance programme of the institution concerned.

With what has been summarized above, in mind, we decided to thoroughly survey the characteristics of the educational programmes of six football academies ${ }^{3}$.

\section{A General Approach to the Educational Programmes and Some Theoretical Aspects}

The educational programmes are to be considered as the basic documents of the educational and training institutions. It is created by the teaching staff of the institution concerned, and the superior authority approves of it in its final form. The document provides a framework to the work of the school, and the programme is tailored to the specific local peculiarities and the needs of the clients/users. It may also be interpreted as some sort of mission statement (Kotschy, 2003) and strategic plan (Kormos, 2010), the function of which is to create the pedagogical principles and practical guidelines of the educational work going on at the institution. Gábri (1998) asserts that one of the major goals of an educational programme is to provide the experts with opportunity, platform for the objective assessment of what is included in the programme and how it is implemented in daily practice. In the author's opinion, one of the preconditions of the success of such an evaluation is that the programme is formulated in a way that it really reflects the tasks, mission, professional activities, the development and schedule of the work in a realistic way. The views of Brezsnyánszky (2000) are similar, as he argues that the educational programmes are documents that can be analysed for a diagnostic purpose. The documents may yield important professional, attitudinal and school-philosophical information, including the image of the children that the teachers of the school possess.

Several authors differentiate between the recommended and required elements of the programmes (for instance, Gábri, 1998; Kormos, 2010). Kormos (2010), in his comprehensive work related to educational programmes and local curricula, establishes the major focus points, organizational units that, in his opinion, should be included in every such programme.

Out of the non-required parts of the programme, the introduction or foreword usually offers some sort of an insight into the life and atmosphere of the institution. It is usually the personal text of the head teacher or principal. That segment contains some of the basic data and information about the institution. In accordance with the Act on Public Education, an analysis of the situation is not a part of the educational programme, but Kormos (2010) believes that it is still worth opening such a chapter, since the institutions are able to provide a view into the characteristics and features they find important to share about themselves. The mission statement describes the philosophy and envisaged mission of the school. The pedagogical programme is a required element of the broader educational programmes. The pedagogical programme is to contain the basic elements of the pedagogical work characteristic of the school, the goals, tasks and means of the work, the specific objectives of the development of the students' personalities, the specific objectives of community development, the challenges regarding the students with special educational needs, the tasks in connection with the development of gifted students. the responsibilities of the school in terms of reducing social inequalities, and the institution-specific health and sanitary regulations (Kormos, 2010).

\footnotetext{
${ }^{3}$ We selected three academies from the capital city and three from the provinces. They are not named, only identified with numbers.
} 
The task of the educational and social department operating at the individual football academies is to supervise the school readiness of the footballers, to prepare them for graduation, as the professionals do at the Károly Sándor Football Academy (Rábai, 2018).

\section{Our Research Methodology and the Circumstances of our Survey}

As it has been referred to above, the focus of our research is the analysis of the educational programmes of the six selected football academies. Our research methods included the analysis of the relevant documents and the semi-structured interviews we conducted with the heads of the educational sections of the schools $(\mathrm{N}=6)$. In the course of our research, the educational programmes of all the six academies were thoroughly analysed. The interviews with the section heads gave us specific information about the educational work of the individual academies.

Even before the actual start of the research, we looked into the question of the availability of the programmes of the Hungarian academies on their websites or in any other way to those interested. The appearance of the programmes to the public was far from being uniform and of the same quality in the case of the individual institutions. In some instances, the educational programmes were not accessible at all on the websites of the academy concerned, or in any other way. We were only given a chance to look at, and analyse the educational programme of these academies at the personal request to the leaders of the institutions in question. In connection with that issue, our definite opinion is that it is useful and desirable to make these documents public, especially because the parents of the present -and future-students of the academies would be able to learn about the principles, concepts, and characteristics of the educational programme, and the educational work based upon those, in the academy they have chosen or wish to choose in the future. Furthermore, in this way the work of the individual academies would become comparable with each other, and with their own principles and preliminarily set goals.

\section{The Results of the Analysis of Documents: a General Overview of the Educational Programmes of the Football Academies in Hungary}

\section{Formal Characteristic Features of the Educational Programmes}

In the course of our survey of the formal characteristics of the educational programmes, we sought answers to the following questions: what is the breakdown of the document (is it a single, longer one, or does it consist of several smaller segments)? How different are the individual documents in terms of size? What structural differences are there between the documents of the individual academies? How much attention do the makers of the documents pay to the reccommended and required elements as suggested by the related literature? What are the specific names of the documents prepared, and what structural differences are there in them? Is the name of the document relevant to its inner content?

The following chart contains the formal parametres of the documents we examined, and a more detailed analysis is provided further on: 
Table 1: Formal Parametres of the Educational Programmes of the Football Academies (Source: the author's own)

\begin{tabular}{|c|c|c|c|c|c|}
\hline $\begin{array}{l}\text { Type of the } \\
\text { academy } \\
\text { (country or } \\
\text { capital city) }\end{array}$ & $\begin{array}{c}\text { The } \\
\text { breakdown of } \\
\text { the document }\end{array}$ & $\begin{array}{l}\text { The size } \\
\text { of the } \\
\text { document } \\
\text { (total } \\
\text { number } \\
\text { of pages) }\end{array}$ & $\begin{array}{c}\text { Structural } \\
\text { arrangement } \\
\text { (chapters and } \\
\text { subchapters) }\end{array}$ & $\begin{array}{l}\text { The appearance } \\
\text { of the } \\
\text { recommended } \\
\text { and required } \\
\text { elements in the } \\
\text { educational } \\
\text { programmes }\end{array}$ & $\begin{array}{l}\text { The name of } \\
\text { the document }\end{array}$ \\
\hline $\begin{array}{l}\text { 1st academy } \\
\text { in the capital }\end{array}$ & $\begin{array}{l}\text { 1 single, } \\
\text { standard } \\
\text { document }\end{array}$ & 48 pages & $\begin{array}{l}\text { Coherent text, } \\
\text { consisting of main- } \\
\text { and subchapters }\end{array}$ & $\begin{array}{l}\text { All the elements } \\
\text { are present, except } \\
\text { for the local } \\
\text { programme }\end{array}$ & $\begin{array}{l}\text {... Academy, } \\
\text { Foundation's } \\
\text { Students' } \\
\text { Home, } \\
\text { Educational } \\
\text { Programme }\end{array}$ \\
\hline $\begin{array}{l}2 \text { nd academy } \\
\text { in the capital }\end{array}$ & $\begin{array}{l}1 \text { single, } \\
\text { standard } \\
\text { document }\end{array}$ & 35 pages & $\begin{array}{l}\text { Coherent text, } \\
\text { consisting of main- } \\
\text { and subchapters }\end{array}$ & $\begin{array}{l}\text { A mere fragment } \\
\text { of the } \\
\text { recommended and } \\
\text { required elements } \\
\text { is present } \\
\text { (introduction, the } \\
\text { objectives and } \\
\text { tasks of the } \\
\text { educational work, } \\
\text { etc.) }\end{array}$ & $\begin{array}{c}\text { Educational } \\
\text { and Training } \\
\text { Programme } \\
\ldots \\
\text { Students' } \\
\text { Sport Motel }\end{array}$ \\
\hline $\begin{array}{l}\text { 3rd academy } \\
\text { in the capital }\end{array}$ & $\begin{array}{l}1 \text { single, } \\
\text { standard } \\
\text { document }\end{array}$ & 13 pages & $\begin{array}{c}\text { No main-and } \\
\text { subchapters, the } \\
\text { wording is chaotic at } \\
\text { places }\end{array}$ & $\begin{array}{l}\text { Only one element } \\
\text { (the goals and } \\
\text { tasks of the } \\
\text { educational works) } \\
\text { appear in the } \\
\text { document }\end{array}$ & $\begin{array}{c}\text {... Academy, } \\
\text { Free time and } \\
\text { educational- } \\
\text { training } \\
\text { programme, } \\
2014-2015\end{array}$ \\
\hline $\begin{array}{l}\text { 1st academy } \\
\text { in the } \\
\text { provinces }\end{array}$ & $\begin{array}{l}1 \text { single, } \\
\text { standard } \\
\text { document }\end{array}$ & 177 pages & $\begin{array}{c}\text { Coherent, extensive } \\
\text { text, consisting of } \\
\text { main- and } \\
\text { subchapters }\end{array}$ & $\begin{array}{l}\text { Apart from the } \\
\text { mission statement } \\
\text { and enclosures (not } \\
\text { required elements), } \\
\text { all the other } \\
\text { elements are } \\
\text { present }\end{array}$ & $\begin{array}{l}\text { Educational } \\
\text { Programme }\end{array}$ \\
\hline $\begin{array}{l}\text { 2nd academy } \\
\text { in the } \\
\text { provinces }\end{array}$ & $\begin{array}{l}1 \text { single, } \\
\text { standard } \\
\text { document }\end{array}$ & 4 pages & $\begin{array}{l}\text { No main-and } \\
\text { subchapters, only a } \\
\text { few headlines }\end{array}$ & $\begin{array}{l}\text { Neither the } \\
\text { required, not the } \\
\text { recommended } \\
\text { elements appear in } \\
\text { the document }\end{array}$ & $\begin{array}{c}\text { Social } \\
\text { division, } \\
\text { educational } \\
\text { division }\end{array}$ \\
\hline $\begin{array}{l}\text { 3rd academy } \\
\text { in the } \\
\text { provinces }\end{array}$ & $\begin{array}{l}\text { Multi-part } \\
\text { document } \\
\text { (a total of } 5 \\
\text { parts) }\end{array}$ & 9 pages & $\begin{array}{l}\text { Not a standard, } \\
\text { uniform document, } \\
\text { the text is arranged } \\
\text { into several separate } \\
\text { documents, the } \\
\text { separate subjects are } \\
\text { laid down in separate } \\
\text { documents in main- } \\
\text { and subchapters }\end{array}$ & $\begin{array}{l}\text { Only the mission } \\
\text { statement and the } \\
\text { development goals } \\
\text { appear in the } \\
\text { document }\end{array}$ & $\begin{array}{l}\text { No overall } \\
\text { title, only the } \\
\text { individual } \\
\text { chapters have } \\
\text { titles }\end{array}$ \\
\hline
\end{tabular}

The majority of the educational programmes provided by the football academies are single documents, we only found one that was broken down into separate sub-documents (3rd academy in the provinces). The programmes are, however, extremely heterogeneous in terms of size, and there is little common in them, since one of the programmes (that of the 1st academy in the provinces) amounts to almost 177 pages, whereas another institution (2nd academy in the provinces) devoted a mere four pages to the subject.

The structural layout of the individual programmes are also largely different from each other. We found coherent educational programmes, divided into main- and subchapters in the case of three of the academies (1st 
and 2nd in the capital city, and the 1st one in the provinces). At the other three academies (the 3rd in the capital city and the 2nd and 3rd in the provinces) we detected considerable shortcomings in the structure of their programmes. So much so, that in certain cases it was not even possible to talk about a real educational programme, as the text we used as the subject of our analysis was provided to us in several different documents academy. But even when we received the educational programme as one single document, we often found shortcomings: the level of elaboration of the recommended and required elements-when they were present at all-was rather uneven and their quality was heterogeneous (Kormos, 2010).

In fact, we did not even find an educational programme which contained all the required and recommended elements listed above. We, however, did find some that contained almost all the elements at a level of satisfactory elaboration (the 1st academy in the capital city, and the 1st in the provinces). At other programmes (2nd and 3rd academies in the capital and the 3rd academy in the provinces) we only found a part or even a small fragment of both the recommended and required elements. At one instance (2nd academy in the provinces), not one single recommended or required element (!) appeared. These differences are considerable, and raise serious questions regarding the standardization and quality of the educational work of the academies.

The names/titles of the documents are also largely heterogeneous, as every single one of the academies we surveyed gave a different name to their respective educational programme. All this suggests that the academies determined and named the formal elements of their educational programmes themselves, and those who worded and compiled the documents are not very experienced, and are slightly uncertain, in pedagogical programme making.

\section{The Characteristic Features of the Contents of the Educational Programmes}

When we analysed the concepts/contents of the educational programmes, we wished to obtain information about the following issues:

- do the documents contain real educational programmes, and if they do, how elaborate and detailed this field is;

- to what extent do the aspects of the development of the children's personality appear, what importance the makers of the programmes attribute to these aspects;

- what image of the child determines the educational strategy of the institutions;

- what values are articulated in the programmes;

- what goals are set for the institution and how are these goals formulated in the programmes;

- are there any concepts or ideas of quality assurance in the programmes; that is, are there any accountable (or any other) criteria of performance at the academies.

At the institutions where we found an educational programme, there was only one academy out of the six (the 1st academy in the provinces) that had an extensive, detailed programme that covered almost all the major aspects (basic educational principles, values, goals and objectives, means of education and fields of instruction). Out of the other five documents, three (1st, 2nd and 3rd academies in the capital city) had an educational programme as a structural unit, but these were largely superficial, not very detailed, some only covered one single aspect. What is, however, important, that the documents of two academies (the 2nd and 3rd academies in the provinces) hardly had any relevance to an educational programme, which is a major shortcoming in the case of these two institutions.

We also intended to examine the personal development schemes of the children, as it is an area closely related to the educational programmes. Furthermore, we wished to look into the role of the teacher. In four of the documents (1st and 2nd institutions in the capital, the 1st and 3rd in the provinces) great significance is ascribed to these areas, emphasizing the importance of developing the personality of the children, the creation of a childfocussed environment, and the presence of highly qualified and devoted teachers. In the case of two of the programmes (3rd academy in the capital and the $2 \mathrm{nd}$ in the provinces), however, there is no reference to these issues, which can only be interpreted as a major shortcoming.

We found disappointing results in terms of the image of the child in the educational programmes analysed. In general, we must state that the educational programmes analysed do not contain any explicit view, image of the child they intend to educate. They do not contain any fundamental chapter the mission of which would be to contain any vision of the age groups attending the academies, of the special pedagogical needs that dealing with 
them requires. On the other hand, in most cases it is possible to deduct or trace back the basic elements of the view of the child from other parts of the document. If that derivative-analytical step is taken, we may see that the image of the pupil or student thus emerging is not in any major way different from those appearing in the educational programmes of ordinary schools that do not have any special profile.

Still, it is to be emphasized that the missing chapter on the image of the pupil/student is a serious shortcoming of the system, for several reasons. The chapter dealing with the image of the child in the educational programme of a football acadamy is supposed to be multi-functional. The parents, whose children attend-or will potentially attend-these academies are, naturally, interested in the educational-pedagogical work going on at these institutions, and such a chapter would support and orient the work of the coaches, trainers and other specialist who wortk there but not have any teaching qualifications.

In terms of values represented, the programmes examined show a rather heterogeneous view. There is a confusion around the terms and definitions used, as value often appears as a synonym of basic principles. It suggests that for those who worded and compiled the documents, the educational-pedagogical role and significance of values were unclear (let alone the traditions of value theory in education). The programmes deal with the task in different ways. Some of them completely avoid the issue, and do not mention value at all. Some do include values i the document, but in a broadly general way, and the values laid down in the text are not directly relevant to the primary profile of the academy, that is, bringing up the new generations, the replacement of athletes. In these instances the values are valid, but they could equally be applied to any educational institution, and they are directly linked to the profile of a football academy or to any sport activity. There are also programmes that contain values that appear to be specific, differentiating a football academy from any other institution of instruction.

An important part of our analysis of the programmes was an examination of the objectives, that is, we wished to find out about the goals the academies set up for themselves, and what areas they give priorities to.

In general, we may conclude that the formulation of the goals and tasks in the documents of the academies is uncertain from a linguistic aspect, as descriptive and prescriptive segments are often intermingled. The definitions of objectives and tasks often overflow into the texts that are supposed to contain the values. The separate elements of the goals and tasks put forward are sometimes logically not linked to each other, they do not constitute an organic unit, the elements are not based upon each other. The tasks, goals and activities do not lead towards a logical process. In these cases the authors of the texts do not apparently make the effort to produce a text that goes beyond the simple appearance of the elements. The elements are, in this way, unable to constitute an organic unit.

It is also clear that the objectives of developing the organization appear simultaneously with, or sometimes even before, the objectives of developing the young members of the academy. What is even more intrigueing is that the real function of the football academies-performing and supporting sport- and educational training-hardly receives any attention. The only exception to that is the 1 st academy in the capital city.

The last aspect of analysing the content of the educational programmes was the issue of quality assurance. In that respect, we encountered nothing surprising, since from what has been stated above it is clear that incomplete, overtly general, simplified and inconsistent educational documents do not contain too many elements that can be easily controlled or verified. In fact, such a verification or control would be nearly impossible, both in the respect of football itself and all the other educational elements. It is therefore not the least surprising that the educational programme documents we analysed contained no elements related to quality assurance, success criteria, feedback mechanisms for the cases of meeting or not meeting the original goals. Where the issues of success or efficiency appear at all, they are restricted to the dimensions of traditional schools, and there is nothing in them about the sport dimension of the academies, the specific aspects related to sport, not even the successes achieved in sport.

When we summarize the analysis of the formal elements and the contents of the educational programmes, we may conclude that documents of all the six football academies are extremely heterogeneous from the aspects of both their formal elements and their contents. At several programmes we found shortcomings that may considerably influence the successful operation of the institution. Our examination found only two educational programmes that come close to the satisfactory level both in their formal elements and contents (1st academy in the capital, and the 1st in the provinces). Although the extent and the structure of these two documents, as well as their contents, stand out among the others, even these two are far from fully acceptable. At the programmes of the other four academies, serious discrepancies are detectable, and the shortcomings seriously jeopardize their acceptability. 


\section{The Interviews Conducted in Connection with the Educational Programmes}

As it has been referred to previously, we conducted interviews in addition to the analysis of the educational programmes of the six football academies. The interviews were carried out with the principals of the educational sections of the academies. We wished to obtain information about the characteristics of the work going on in those sections. Our questions in connection with the work of the teaching sections were extended to several areas, for instance, how the heads of these sections are recruited, how they are motivated, the structure and concept of the present working order, as well as the difficulties and challenges they face, and their recommendations for future development.

It is to be noted that none of the section heads we interviewed had worked at another football academy before, and with the exception of one (the 3rd academy in the capital), all of them possessed some educational/teaching qualification.

We requested the section principals to show us the characteristics, working guidelines of their own educational-social sections. Our respondents confirmed that some sort of an educational-social section was in operation at each of the six academies. The major differences between them were generated by whether they are open (e. g. the 2nd academy in the capital, the 1st, 2 nd and 3rd in the provinces) or closed academies (e. g. the 1st and 3rd academies in the capital). The basic difference between the two types is that while the open academies do their educational work in cooperation with different basis schools, integrating their pupils and students into the classes of the external basis schools, the closed academies organize the teaching of their members on their own premises. At the closed academies, teachers usually come to the academy during the mornings to teach the children, and their classes closely match the football training sessions of the young members of the academy.

In this situation, the education at the closed academies is subject to a very tight schedule, and the workload of the children is high, almost every day. According to the opinion of our interviewees, at the open academies the most important criterion of choosing the basis school is its distance from the academy. When they choose secondary schools, they attempt to direct students and parents towards specific secondary schools, but excessive pressure is, naturally, avoided, as it would be highly improper.

The academies teaching secondary school students make efforts to send their students to sport-biased secondary schools in the public education system, as these are the schools that tend to be the most flexible in connection with the absences of the students for sports reason. One of our respondents (2nd academy in the capital city) told us that they usually target the general grammar schools as the venues of the academic instruction of their students, and not so much the ones specialized in sports, because the latter organize a lot of trainings and other events for the afternoons and weekends. This system is not really compatible with academy-level sport activities.

During our interviews, several section heads emphasized the importance of studying. As one of our respondents pointed out (1st academy, capital city) in connection with the issue: "A precondition of high-level sport activities is the presence of proper cognitive skills. We also need to develop the mental side of our students."

At all the academies we examined, great attention is paid to effectively organizing the academic instruction of the pupils and students. At one of the institutions, academic instruction and the development of the human personality were among the most important principles, in addition to training and education in sports, as early as the foundation of the academy. Their educational section, its operational concept, was created and developed in accordance with those ideas.

Our respondents revealed a wide range of similarities in the operation of the academic sections of the individual akademies. The heads and deputies of the educational sections participate in the work of their sections, and so do the teachers who are in direct connection with the students accommodated in the dorms. Talent development projects are in operation at some of the academies (at the 3rd academy in the capital city, for instance, they won financial support at applications for the purposes of extra foreign language courses). There are also possibilities for organizing catching up courses at which those are assisted who are lagging behind in some subjects or struggle with learning difficulties. Another important role of the professionals working at the educational-social section is serving as some sort of a bridge or link between the institutions of education and the coaches, continually relaying to the coaches information pertaining to the learning efficiency of the students, the positive or negative events in connection with the schools. They are also supposed to be in connection with the parents of the students of the academy. Our respondents reported that they are in continual connection with the head teachers, and they are usually on good terms with the basis schools, although several of them remarked that sometimes skirmishies or difficulties occur. They are, however, able to solve these sooner or later. Most of the conflicts are caused by the 
too frequent absence of the students because of the sports events they participate in (e. g. championships, matches) and some schools find it difficult to handle that.

Our interviewes found the introduction of the electronic class register a great achievement, since in this way they are able to monitor the academic progress of the footballers. The section heads also accounted that the academies always created the sections and determined the work of the new sections themselves, without any preliminary cooperation or professional consultation. One of our respondents (1st academy in the capital) remembered that the section had existed and worked the section in an informal was before the Double Pass appeared and made their survey. The section only became official when the Belgian company started their examinations, as they company evaluates and scores the work of the section as an official unit.

It led us to the question why the section heads of the football academies do not have any professional discussions regarding the work of their own educational and social sections, thus assisting each other, and opening the way for sharing, exchanging good practises. One of our interviewees (1st academy in the provinces) responded the following in connection with that:

"I keep thinking on what else we could change a little bit. That is why I want to go to each academy and see how they are doing it, because we need to take over what is good. Maybe that they have a good idea, maybe I have one. We need to attend professional discussions where everybody tells the others about their own experience, and eventually they and we can be more successful and efficient."

Now it seems that although there was no opportunity for preliminary discussions and orientation when the programmes were launched, and there were no adaptable alternatives when the academies were founded, today there appears to be a powerful need for professional discussions with regards to the work of the sections, thus promoting the exchange of ideas and good practices, or even starting joint efforts to solve a nerw problem that crops up. It is, however, doubtful that such joint work may take place, since the attitude of the acedemies to the public and publicity definitely reinforces that doubt.

Our interviewees are not fully satisfied with the quality of the programmes. Almost every one of them pointed out that "there is always a chance for further progress and development," so it seems that the efficiency may be further polished and improved at almost all the academies. The also mentioned the difficulties they face, for instance they believe that they could only be really efficient if they worked full time, dealing 8 hours a day with their sections. One of our respondents (the 1st academy in the provinces) expressed his dissatisfaction with the infrastructural conditions, which is surprising since that is the category where the Hungarian football academies are usually the best equipped. Our interviewee, however, wanted a place where the students coming to the training sessions too early could sit down to study or pass the time.

The section head of another academy (the 3rd in the provinces) also mentioned some shortcomings in the infrastructure and facilities. They would be happy to see a united, standard institution, a kind of a sports collegium where the academic instruction of the pupils and students could take place and where they could also spend their free time under the same roof. Such an institution would improve the loyalty of the players to their respective clubs as well.

As far as the potential directions of development are concerned, several of our interviewees identified the efficiency of the connections between the academies and the schools as an area that definitely need improvement. One of our respondents (2nd academy in the provinces) disclosed to us that skirmishes are the most frequent with the schools run by religious denominations, as those institutions have different pedagocial principles and the schools have different priorities. Consequently, unexpected or unplanned sports events lead to problems between the football academy and the schools of that category. Another interviewee (2nd academy in the capital city) would like to increase the pool of basis schools, but can only imagine schools that have no objections to the pupils' and students' commitments in connection with sports. The same respondent also mentioned the cooperation and communication problems between the academies and the schools, a part of which is that schools only contact them as a last resort, although the problems could be more easily remedied at an earlier stage.

Our interviewee also added that they often experience the negative stereotypes about the sport they do, and it well illustrates the prestige of work of the educational-social section of the acadcemies as well. 


\section{Conclusions}

At the outset of our research project, our preliminary hypothesis was that the practical work of the institutions dealing with bringing up the replacement for football is pedagogically conscious and well-founded, so we expected that they had an educational programme-the foundation of educational work-similar to other-that is, ordinaryschools.

In order to identify the specific characteristic features of the document concerned, we first surveyed the related international literature, dealing with the formal features and typical contect of educational programmes. In possession of what we learned in as much of the international literature as was available to us, we carried out the analysis of educational programmes of the academies (publicly available documents, and sometimes obtained in a more difficult way).

Our analysis of the educational documents of the football academies concentrated first on the formal dimensions of the programmes, then their contents. Our final conclusion is that the educational programmes of the six football academies we dealth with are extremely heterogeneous, both in terms of their formal features and their contents.

Heterogeneous nature was certainly not the only shortcoming we encountered. Several documents simply lacked some of the important-and universally approved-chapters, and so the quality of these documents left a lot to be desired. We may, furthermore, conclude that the applicability of the incomplete and not very elaborate programmes is dubious from a quality assurance aspect as well: once the goals are not clearcut and specific, what can one check in connection with the operation of the organization? All our findings cloesely match the results of the 2016 audit conducted by Double Pass. ${ }^{4}$ The experts of the Belgian company, as a conclusion of their examination, also pointed out the qualitative and quantitative shortcomings of the documentation.

We conducted interviews with the heads of the educational and social sections of the academies as a complementary measure to the document analyses. In the course of the interviews, we wished to obtain detailed information about the work of the sections. The interviewees accounted that there are several experts at every section, and they are able to share the special tasks, thus reinforcing efficiency of the sections. What we had concluded from the document analysis, however, was confirmed by the interviews: every single football academy established and developed its own section and educational programme according their own individual ideas and principles. It was not preceded by any professional discourse, discussion, or thorough preparation on the side of the section heads. The lack of any such preparation was referred to by several of our respondents, who believed that a coordination or joint professional preparation would have probably improved the standards of the documents as well. It is clear from all this that the individual pedagogical programs have nothing to do with the school framework curricula, as they have been individually designed. We agree with the section heads that the lack of the preliminary professional orientation and preparation is the most serious shortcoming of the system.

On the whole, we may assert that although the academies have their own educational-social sections, the quality of the documents that serve as a basis of the educational work is far from satisfactory. The academies ought to pay a lot more attention to the standards of their educational programmes, as most of them are at present incomplete, key elements are missing, and they may show a false image of educational work going on at the academy. Parents or outsiders will not receive a true image of the educational-pedagogical work at the institution. It is also to be noted here that access to the documents is not always easy, as several academies do not make any effort to make documents readily available to the public.

\section{References}

Brezsnyánszky, L. (2000). Dialógus az iskolák pedagógiai programjaiban [Dialogue in school pedagogical programs]. In L. Brezsnyánszky (Eds.), Pedagógiai programok elemzése [Analysis of Pedagogical Programs] (pp. 9-22). Debreceni Egyetem BTK Neveléstudományi Tanszék.

Collin, A., \& Young, R. (2000). The Future of Career. Cambridge University Press.

Gábri, K. (1998). A pedagógiai program mint az iskolai értékelés alapja [The pedagogical program as the basis of school evaluation]. Új pedagógiai szemle, 48(9), 41-50.

Kormos, V. (2010). Módszertani összefoglaló [Methodological summary]. INTER-STUDIUM.

Kotschy, B. (2003). Az oktatás célrendszere [The target system of education]. In I. Falus (Eds.), Didaktika [Didactics]. (pp. 107-134). Nemzeti Tankönyvkiadó.

\footnotetext{
${ }^{4}$ Source: https://www.mlsz.hu/wp-content/uploads/2016/06/DP_glob\%C3\%A1lis-jelent\%C3\%A9s.pdf
} 
Nerland, E. \& Saether, S. A. (2016). Norwegian football academy players - Players self assessed competence, Perfectionism, Goal orientations and Motivational climate. Sport Mont, 14(2), 7-11.

Orosz, R. (2009). A labdarugó tehetség kibontakozását befolyásoló pszichológiai tényezök vizsgálata [Investigation of psychological factors influencing the development of football talent]. Doctoral dissertation.

Pruna, R., Tribaldosb, L., M., \& Bahdur, K. (2018). Player talent identification and development in football. Apunts Med Esport, 53(118), 43-46.

Rábai, D. (2018). A magyar labdarugó akadémiai rendszer kialakulásának története és a Sándor Károly Labdarugó Akadémia jelen gyakorlatának bemutatésa [The history of the development of the Hungarian football academic system and presentation of the current practice of the Sándor Károly Football Academy]. Magyar Sporttudományi Szemle, 19(74), 52-58.

On-line sources:

https://www.doublepass.com/

https://www.mlsz.hu/wp-content/uploads/2016/06/DP_glob\%C3\%A1lis-jelent\%C3\%A9s.pdf

(C) 2020 by the authors. Submitted for possible open access publication under the terms and

conditions of the Creative Commons Attribution (CC BY) license
(http://creativecommons.org/licenses/by/4.0/). 